\title{
Kodinperustamislainajärjestelmän käytäntööntulo Suomessa
}

Kirjoittanut Armas Nieminen.

\author{
Johdanto.
}

Syntyvyyden vähenemisen ehkäisemiseksi ja jatkuvan väenlisäyksen varmistamiseksi nykyaikainen väestöpolitiikka on pyrkinyt poistamaan - mikäli se valtiovallan toimenpitein on mahdollista - lapsiköyhyyden syitä. Eräs näitä on, että taloudellisten edellytysten puuttuminen suuresti vaikeuttaa monien menoa naimisiin ainakaan sïnä iässä, jolloin perheen perustaminen ihmisen ruumiillisen ja henkisen kehityksen kannalta katsoen on luonnollisinta.

Naimattomuuden vaikutus syntyvyyteen on ilman muuta selvä. Mutta tilasto osoittaa, että myöskin naimisiinmenoiällä on tässä suhteessa, kun tarkastellaan avioliittoja joukkoilmiönä, suuri merkitys, joten aikaisten avioliittojen tärkeyden tähdentämiseen väestöpoliittiselta kannalta on täysi syy. Esim. Tanskassa syntyneisyyden on katsottu alentuneen hitaammin kuin Ruotsissa ja Norjassa juuri sen vuoksi, että avioliittoisuus on siellä ollut suurempi ja että suhteellisesti suurempi osa väestöä on mennyt naimisiin lisääntymiskykyisessä iässä kuin viimeksimainituissa maissa.

Voimatta tässä yhteydessä ryhtyä tarkemmin tekemään selkoa Suomen avioliittotilaston tosiasioista mainittakoon vain yleisesti, että useihin maihin verrattuna, joissa syntyneisyys on suunnilleen sama kuin Suomessa, avioliittoisuus on meillä alhaisempi ja että 
huolimatta täällä ajoittain esiintyneistä verrattain korkeistakin avioliittoisuusluvuista hedelmällisessä iässä olevien avioparien suhteellinen määrä näyttää viimeisen sukupolven aikana Suomessa jatkuvasti supistuneen. Tähän viittaa m.m. se, että läsnäolevaan väestöön kuuluvista 45 -49-vuotiaista naisista oli naimattomia vuonna 1910 vain $14,7 \%$, vuonna $192017,1 . \%$, vuonna 1930 jo $21,0 \%$ ja vuonna 1940 kokonaista $23,5 \%$. Avioliittoikä taas on jatkuvasti noussut. Kun esim. vuosikymmenellä 1891-1900 naimisiin menneistä miehistä $37,8 \%$ ja naisista $60,0 \%$ solmi avioliiton alle 25 -vuotiaina, olivat vastaavat luvut vuosikymmenellä $1931-1940$ enää vain $28,1 \%$ ja $50,9 \%$.

Taloudellisista syistä, jotka yhdessä kaupungeissa vallitsevan naisten enemmyyden, ihmisten kasvaneiden elämänvaatimusten ja entistä vapaamman sukupuolimoraalin ohella ovat vähentäneet naimisiin menoa nuorella iällä, tärkeimpiä ovat olleet ammattikoulutuksen pitkällisyys, opiskeluaikana tapahtunut velkaantuminen ja palkkauksen suhteellinen alhaisuus ansiotoiminnan alkuaikoina sekä työttömyyden aiheuttama toimeentulon epävarmuus. Tällaisten perheenmuodostusta ehkäisevien syiden vaikutuksen vastustamiseksi on yhteiskunnan toimesta ryhdytty taloudellisesti tukemaan avioliittoon aikovia, ja tähän tarkoitukseen on yleensä pidetty ns. avioliitto- eli kodinperustamislainoja, joiden avulla kodin perustamisesta aiheutuvat kertamenot saataisiin suoritetuiksi, sopivimpana keinona.

\section{Avioliittolainat ulkomailla.}

Kun kodinperustamislainoja Suomessa ennen viimeisiä sotia ryhdyttiin suunnittelemaan, oli jo olemassa ulkomaisia kokemuksia vastaavanlaisesta lainsäädännöstä. Avioliittolainat oli nimittäin jo otettu käytäntöön Saksassa (1933), Italiassa (1937), Ruotsissa (1938) ja Ranskassa (1939), ja näin tapahtui sittemmin myöskin m.m. Espanjassa (1941), Unkarissa (1942), Bulgariassa (1943) ja eräissä ulkoeurooppalaisissa maissa, kuten Brasiliassa (1941).

Vaikka näissä kaikissa maissa vallitsevien järjestelmien perimmäisenä tarkoituksena onkin ollut lisätä avioliittoisuutta ja aikaista naimisiin menoa sekä siten välillísesti syntyvyyttäkin, poikkeavat 
lainsäädännön yksityiskohdat kuitenkin poikenneet toisistaan tuntuvasti. Ruotsissa kodinperustamislainoilla on selvä sosiaalipoliittinen leima, kun taas Saksan lainoille, kuten valtiojohtoisten maiden väestöpolitiikalle yleensäkin, on ollut ominaista painopisteen asettaminen korostetummin lasten luvun mahdollisimman suureen lisäämiseen. Siten Saksassa on pyritty syntyvyyden enentämiseen suoranaisemmin kuin Ruotsissa palkitsemalla lasten synnyttämistä lainoista tehtävän vähennyksen avulla; lainat ovat lisäksi olleet korottomia, ja niiden kuoletus on ollut järjestetty lainansaajille mahdollisimman edulliseksi. Ruotsissa taas on vain tyydytty tukemaan nuoria kodin perustamisessa, jotta tällöin esiintyvien menojen suuruus ei viivästyttäisi avioliiton solmimista. Maksuehtoihin katsoen Ruotsin järjestelmä on rakentunut enemmän pankkitoiminnan pohjalle kuin Saksan, osaksi valtion menojen säästämiseksi, osaksi sen vuoksi, että vältyttäisïn antamasta lainoille köyhäinavun luonnetta. Ruotsissa onkin vedottu yleensä enemmän kuin Saksassa lainansaajain henkilökohtaiseen vastuukykyyn, mikä seikka on ilmennyt melko tiukoissa lainaehdoissa. Paitsi Saksalle ominaista rotu- ja terveysnäkökohtien sekä poliittisen kannan huomioonottamista mainittakoon näiden järjestelmien välisistä eroavaisuuksista vielä, että viimeksimainitussa maassa lainanantoon on liittynyt muitakin kuin puhtaasti väestöpoliittisia tarkoituksia, ennen kaikkea työttömyyden vastustaminen m.m. houkuttelemalla nainen ansiotyöstä kotoisiin askareihin, minkä vuoksi lainansaanti on naisten osalta ollut rajoitettu ansiotyössä olleisiin, sekä maaltapaon vastustaminen. Yhteistä molemmille järjestelmille taas on ollut m.m. se, että ikä- ja tulorajaa ei ole kummassakaan määrätty.

Ranskassa avioliittolainoja on myönnetty ainoastaan maalaisväestölle, ja niiden päätarkoituksena on ollut maaltapaon ehkäiseminen ja lasten lukumäärän lisääminen. Lainojen kuoletus on niiden maalaisluonteesta johtuen jakaantunut pitkän ajanjakson osalle, ja se on lasten syntyessä tehtävien lyhennysten muodossa ollut järjestetty samaan tapaan kuin Saksassa; lainat eivät kuitenkaan ole olleet korottomia. Sitäpaitsi on lainansaajain ylimmäksi ikärajaksi määrätty 30 ikävuotta.

Italian ja Unkarin avioliittolainajärjestelmissä on ollut monia yhteisiä piirteitä Saksan järjestelmän kanssa, varsinkin lainojen 
kuoletuksen järjestelyssä.. Saksan lạ̈nsäädännöstä poiketen näișạa molemmissa maissa on kuitenkin lainansaajille ollut määrätty sekä ikä- että tuloraja, joskin edellinen on Italiassa ollut otettu käytäntöön vain naișiin nähden. Myöskin Espanjassa ja Bulgariassa, on lainojen kuoletus ollut riippuvainen lasten syntymisestä.

\section{Väestökomitean ehdotus}

Suomessa avioliittolainojen käytäntöönottoa ryhdyttiin virallisella taholla valmistelemaan vuonna 1939. Tällöin nimittäin vuonna 1937 asetetussa tohtori C. O. Frietschin puheenjohdolla toimivassa valtion väestökomiteassa alettiin tutkia tämän uudistuksen toteuttamismahdollisuuksia meillä. , Sotien aiheuttamat keskeytykset haittasivat kuitenkin työtä ja viivästyttivät ehdotuksen valmistumista. Mutta tämä pitkittyminen koitui asialle ehkä eduksikin, sillä juuri tänä aikana maassamme syntyi vilkas väestöpoliittinen harrastus. Nuorten miesten pitkällinen sotapalveluksessa olo sekä kodinperustamistarvikkeiden kallistuminen hintojen yleisen kohoamisen mukana taas aiheuttivat, että taloudellisen tuen tarve koteja perustettaessa muodostui entistäkin kipeämmäksi ja että uudistuksen toteuttamisesta esim. sanomalehdistössä alkoi näkyä keskustelua ja tiedusteluja.

Kysymyksen ajankohtaisuutta todisti, että asia myöskin eduskunnassa nostettiin vireille. Helmikuussa 1942 jättämässään toivomusaloitteessa edustaja $R$. G. Kallia y.m. siten ehdottivat syntyvyyden lisäämiseen tähtäävillä perusteilla hyväksyttäväksi toivomuksen, että hallitus kiireellisesti antaisi eduskunnalle esityksen avioliittolainojen myöntämisestä sellaisille avioliittoon meneville, joilla ei itsellään ole varallisuutta. Seuraavilla valtiopäivillä aloite kuitenkin hylättiin, koska asia tuli väestökomitean mietinnön muodossa valtioneuvoston käsiteltäväksi. Sen sijaan eduskunta myöhemmin, toukokuun 8 päivänä 1944, hyväksyi edustaja Jorma Tuomisen y.m. toivomusaloitteen, että hallitus m.m. ryhtyisi toimenpiteisiin sodasta palaavien asuntokysymyksen järjestämiseksi ja heidän kodinperustamismahdollisuuksiensa tukemiseksi. Tämän aloitteen perustelujen joukossa mainittiin, että valtiovallan tukea aikanaan kotiutettaville miehille tarvittaisiin huomattavassa mää- 
rässä kodinperustamislainojen myöntämisen tai samaan tarkoitukseen annettavien valtion takuiden muodossa. Mitä kauemmin sotaaịkaa kesti, sitä ilmeisemmäksi kävi, että kerran koittavan demobilisaation tullessa ei tuhansien sodan aikana perustettujen tai rauhan pạlațtua välittömästi perustettavien nuorten perheiden elạmää iłman valtion taloudellișia tukemistoimenpiteitä voitaisi palauttaa normaalisiin uomiinsa.

Väestökomitean ehdoțus laiksi ja asetukseksi kodinperustamislainoista jätettiin valtioneuvostolle helmikuun 19 päivänä 1943..$^{-}$Koska lainojen tarkoituksena tuli nimenomaan olemaan tehdä nuorillepareille taloudellisesti mahdolliseksi selviytymisen oman kodin pystyttämisestä aiheutuvista kertakaikkisista menaista, komitea ehdotti otettavaksi avioliittolainójen sijasta käytäntöön nimityksen kodinperustamislainat.

Kodinperustamislainoja koskevaan väestökomitean ehdotukseen sisältyi piirteitä sekä Ruotsin ețä Saksan vastaavista järjestelmistä. Aluksi komiteassa oli ajateltu ehdottaa lainat myönnettäviksi varsinaisina lainoina ilman mahdollisuutta kuolettaa niițä lasten syntyessä tehtävillä vähennyksillä. Asiaa tarkoin harkittua päädyttiin kuitenkin järjestelmään, jossa neljäs osa lainasta kuoleutuisi jokaista lainan myöntämisen jälkeen syntynyttä, kuusi kuukautta elänyttä. lasta kohden, kuitenkin vain sikäli, kuin lainaa vielä olisi jäljellä, Täten laina neljännen lapsen synnyttyä kuoleutuisi kokonaan. Tällaista järjestelmää pidettiin väestöpoliittisesti edullisimpana, ja lisäksi ajateltiin sen avulla voitavan samalla tasoittaa lasten huoltamisen aiheuttamia kustannuksia. Koska näitä näkökohtia oli pidettävä hyvin tärkeinä, komitea ei tyytynyt vähemmillä kustannuksilla toteutettavissa olevaan vaihtoehtoon. Kun ehdotuksen tämä kohta oli saksalaisen järjestelmän kanssa sopusoinnussa, oli taas Ruotsin vastaavasta lainsäädännöstä omaksuttu periaate, että lainasta oli maksettava korkoa ja että se oli kuoletettava määräajassa.

Koska kodinperustamislainojen nimenomaisena tarkoituksena oli edistää aikaista avioliittoon menoa, komitea ehdotti lakiin

1 Uudistuskysymystä oli valmistellut komitean verotusjaosto, johon kuuluivat komitean puheenjohtaja sekä professori Hugo E. Pipping ja kunnallisneuvos Janne Koivuranta. 
otettavaksi säännöksen, ettei kumpikaan lainanhakijoista saa olla täyttänyt 30 vuotta. Jotta taas lainoja myönnettäessä ei suosittaisi avioliittoja, joista todennäköisesti syntyisi sielullisesti tai ruumiillisesti sairaita jälkeläisiä, ja jotta aviopuolisot eivät vaarantaisi toistensa terveyttä, ehdotettiin lainansaannin edellytykseksi pantavaksi, että lainan antaminen on suositeltavaa huomioonottaen lainanhakijain terveydentilan ja heissä mahdollisesti piilevät perinnölliset sairaalloiset ominaisuudet. Lainan tarkoituksenmukaisen käytön sekä koron ja kuoletusmaksun säännöllisen suorittamisen varmentamiseksi taas - mitään takuuta kun lainansaajilta ei vaadittaisi - olisi lainanhakijat tunnettava huolellisiksi ja taloudellisesti harkitseviksi henkilöiksi sekä sellaisiksi, että lainan antaminen olisi suositeltavaa myös heidän elintapoihinsa katsoen. Lisäksi olisi lainansaajien asuntoirtaimiston oltava laina-ajan palovakuutettu suomalaisessa vakuutuslaitoksessa vähintään lainasumman suuruisesta määrăstä. Muina lainan saannin välttämättöminä edellytyksinä oli oleva, ettei lainanhakijoilla ole tarpeeksi varoja oman kodin perustamiseen, että he molemmat ovat Suomen kansalaisia tai että he vakuuttavat aikovansa jäädä Suomeen asumaan, että, jos lainanhakijat ovat naimisissa, erikoiset olosuhteet ovat aiheuttaneet lainan hakemisen vasta avioliittoon menon jälkeen sekä että hakemus on tällöin jätetty vuoden kuluessa avioliiton solmimisesta.

Kodinperustamislainoista oli komitean ehdotuksen mukaan maksettava korkoa kiinteän, lainaa myönnettäessä määrättävän korkokannan mukaan. Niiden takaisinmaksu oli suunniteltu tapahtuvaksi vuotuisilla kuoletusmaksuilla. Laina-aika olisi yhdeksän vuotta, joten siis kuoletusmaksun suuruus olisi kahdeksas osa lainan alkuperäisestä määrästä. Maksujen suorittaminen alkaisi kuitenkin vasta toisena lainausvuonna, koska ensimmäisen lapsen syntyminen yleensä aiheuttaa vanhemmille eniten kustannuksia.

Jotta lain täytäntöönpanossa väestöpoliittiset näkökohdat tulisivat mahdollisimman suuréssa määrässä otetuiksi huomioon, komitea ehdotti, että lainojen myöntäminen uskottaisiin sosiaaliministeriölle. Lainaustoimintaa (m.m. hakemuslomakkeiden jakelu ja vastaanotto, neuvonta sekä lausuntojen antaminen ministeriölle hakemusten johdosta) hoitavana viranomaisena kussakin kunnassa tai useampien kuntien ryhmässä taas olisi paikallisasiamies. Lainat 
oli maksettava lainansaajille osto-osoituksina, joilla saisi hankkia vain määrättyihin ryhmiin kuuluvia tavaroita erikoisten luettelojen mukaan. Osto-osoitusten antaminen, kuoletusmaksujen periminen ja muu lainausliikkeen rahallisen puolen hoito ehdotettiin uskottavaksi postisäästöpankille, joka hoitaisi lainausliikettä postitoimipaikkojen välityksellä.

Ehdotuksessaan väestökomitea myöskin huomautti väestöpofiittisen valistustyön tärkeydestä kysymyksessä olevaakin lainsäädäntöä toteutettaessa. Sen vuoksi olisi julkaistava ja levitettävä kirjasia, joissa lainajärjestelmää selostettaisiin, sekä harjoitettava myös valistustoimintaa. Nämä tehtävät voitaisiin lähinnä antaa maan molemmille väestöliitoille.

Järjestelmän aiheuttamia kustannuksia arvioidessaan komitea päätyi tulokseen, että lainansaajain todennäköinen luku olisi 10.000 vuodessa. Kun lainan enimmäismääräksi oli ajateltu 10.000 markkaa, tultaisiin lainoja siis vuosittain antamaan noin 100 miljoonan markan arvosta.

\section{Komitean ehdotuksesta annetut lausunnot}

Väestökomitean mietinnön johdosta sosiaaliministeriö pyysi valtiovarain- ja kansanhuoltoministeriön, Maalaiskuntien Liiton, Snomen Kaupunkiliiton, Väestöliiton, Suomen Naisten Kansallisliiton ja Suomen Ylioppilaskuntien Liiton lausuntoa. Vastauksissaan nämä kaikki selittivät olevansa komitean kanssa yhtä mieltä kodinperustamislainalainsäädännön toteuttamisen tarpeellisuudesta. Valtiovarainministeriön kansantaloudellisen neuvottelukunnan työvaliokunta, jonka lausuntoon ministeriökin yhtyi, ja Väestöliitto knitenkin asettuivat sille kannalle, että, perhelisän määrän korottaminen olisi väestöpoliittiselta kannalta katsoen vielä kiireellisempää kuin kodinperustamislainojen käytäntöönotto ${ }^{1}$ ja että viimeksimainitun uudistuksen toteuttaminen olisi suunniteltava nimenomaan kotiutettavia rintamamiehiä silmälläpitäen.

1 Vuoden 1945 alusta lukien perhelisän määrää kaikissa kalleusryh. missä korotettiinkin 200 markalla, mutta tämä toimenpide johtui rahan arron alenemisesta. 
A Komitean ehdotuksen sisällön suhteen lausunonantajat esittivät useita muistutuksia. Ensinnäkin lainójèn tarkortukseen' ja nïiden saannin edellytyksiin nähden valtiovarainministeriö huomautti, että mikäli m.m. rintamamiehiä avustettaessa otettaisiin väesstöpoliittiset näkökohdat huomioon, voitaisiin ajatella kahden erilaisen avioliittolainatyypin ottamista käytäntöön, joista toinen, uudisviljelijäin laina, olisi pitkäaikainen erikoislaina ja sellaisena hývin sopivả kuoletettavaksi lasten luvun lisääntymisen perusteella; toinen taas lyhytaikainen huonekalulaina, johon tällainen kuoletustapa soveltuisi vain erinäisin varauksin. Suomen Kaupunkiliitto taas katsoi, että mikäli osoittautuisi tarpeelliseksi rotuhygieeniseltä kannalta kehittää säännöksiä avioesteistä, tämän tulisi tapahtua ylèisestí àviohiittolain puitteissa eikä rajoittaa valvontaa vain niihin tapauksiin, jotka joutuisivat käsiteltävänä olevan lain alaisuutèen, sekä piti ehdotettua viranomaisten velvollisúutta kiinnittää huomiota nî̉n arkaluontoisiin asioihin kuin hakijain elintapoihin kohdistuvana vähemmän tarkoituksenmukaisena. Suomen Naisten Kansallisliitto kaipasi ehdotuksesta määräystä, että lainanhakijat olisi velvoitettava alistumaan sosiaaliministeriön määräämän lääkärin tarkastettavaksi.

Kaikki lausunnonantajat pitivät 10.000 markkaa liian pienenä lainan enimmäismääräksi, kun oli huomioon otettàva kodin perustamiseen tarvittavien välineiden ja tarvikkeiden suuri hinnannousu. - Ehdotettua yhdeksän vuoden laina-aika taas valtiovarainministeriö, Suomen Kaupunkiliitto ja Väestëliitto pitivät liian pitkänä siinä tapauksessa, että lapsia ei synny, mutta Suomen Ylioppilaskuntien Lirtto liian lyhyenä, jos tarkoituksena on, että nelilapsi² nen pérhe lainan yleensä saisi kuoletetuksi ilman korkomaksuja. Suomen Kaupunkiliitto piti kysymyksenalaisena, koituisiko vastaavaa hyötyä siitä, että näistä lainoista perittäisiin mitään korkoả ainakaan muilta kuin lapsettomiksì jääviltä aviopareilta.

Eniten muistutuksia esitéttiin komitean ehdottamaa kuoletusjärjestelmää vastaan. Niinpä valtiovarainministeriö ja Väestöliitto huomauttivat, että jos yhteiskunnan antama lapsiaviustus tehtäisiin riippuvaksi lainan ottamisesta, kuten komitean ehdotus edellytti, juuri yritteliäimmät, omaan apuunsa luottavat avioparit jäisivät lapsiavustuksista osattomiksi. Täten lainavarojen käyttöön houku- 
teltaisiin sellaisiakin, jotka eivät olleet niiden tarpeessakaan. Sitäpaitsi saattaisi ehdotetun kuoletusjärjestelmän vallitessa ensimmäisestä ja toisesta lapsesta koitua suurempi etu kuin seuraavista, joidên ośalta ehkä ei enää jäisi mitään kuoletettavaa. Tämä haitta vớtaisiin välttää siteń, että ensimmäisen ja tờsen Iapsen 'synnyttyä vain keskeytettäisiin kuoletusten suorittaminen vuodéksi ja että vàrsinainen kuoletusten korvaminen lapsilla tulisi kysymykseen vasta kolmannen ja neljännen lapsen syntyessä. Myöskin Suomen Naisten Kansallisliitto asetti kysymyksenalaiseksi, käytettäisiinkö itsè asiassa varsin rajoitetut, yleisiin lapsiavustuksiin liikenevät valtion varat kohtuullisimmalla ja edullisimmalla tavalla suorittamalla täten korvausta nuortenparien ensimmäisistä lapsista, kun toisaalta suuriperheisille vain hyvin rajoitetusti riitti vastaavia avustuksia, sekä piti aiheellisena määrätä kuoletusmaksun suorittamisen alkamaan vasta kolmantena lainavuonna. Kansanhuoltoministeriö taas esitti harkittavaksì, olisiko väestönkasvun edistämüsen kannalta tarkoituksenmukaisempaa määrätä komitean ehdottaman muttumattoman kuoletusprosentin asemesta ensimmäisistä lapsista pienempi, myöhemmistä suurempi lainan kuoletus. Suomen Kaupunkiliitto, samoin kuin useat muutkin lausunnonantajat, esitti kuukausittain tapahtuvaa kuoletusmaksujärjestelmää sekä puolsi otettavaksi käytäntöön esim. kuuden kuukauden pituisen lapsen syntymästä luettavan kuoletusvelvollisúudesta vapaan ajanjakson. Suomen Ylioppilaskuntien Liitto ehdotti, että kustakin lapsesta koituva vähennys olisi viides osa lainasummasta.

Myöskään komitean esittämään laina-asiain hallinto-organisaatioon kaikki lausunnonantajat eivăt olleet tyytyväisiä. Maalaiskuntien Liitto ei pitänyt tarkoituksenmukaisena, että lainaustoiminnan paikallinen hoito annettaisiin sosiaáliministeriön määräämille asiamiehille, koska he joka tapauksessa tulisivat tarvitsemaan kunnallisten viranomaisten apua, vaan puolsi tehtävän antamista kunnallislautakunnille. Suomen Kaupunkiliitto taas ei - kannattanut ehdotettua keskitystä, jonka se katsoi johtavan asiain käsittelyn valitettavaan viivästymiseen, vaan suositteli láinoja koskevain asiain hờdon jättämistä yhteisesti paikallisasiamiehille ja kuntien huoltolautakunnille. Jälkímmäisillã elimillähän jo oli muitakin väestöpofitirïkan piiriin kuuluvia tehtävià. 


\section{Rintamamiehiä koskeva laki säädetään}

Kun hallitus syyskuun 6 päivänä 1944 antoi eduskunnalle kodinperustamislainojen käytäntöönottoa tarkoittavan lakiehdotuksen, havaittiin, että edellä selostetut väestökomitean mietinnöstä annetut lausunnot olivat melkoisesti vaikuttaneet esityksen sisältöön. Huomattavin muutos oli tapahtunut siinä suhteessa, että uudistus tällä kertaa rajoitettiin koskemaan vain sodanaikaisessa sotapalveluksessa olevia tai olleita asevelvollisia ja heidän vaimojaan tai kihlakumppaneitaan, ja heistäkin vain eniten tarvitsevia. Tämä lainansaajain piirin supistaminen aiheutui siitä, että valtion varojen tila ei sallinut kodinperustamislainojen antamista kaikille, joille sen myöntäminen olisi ollut suotavaa, ja kun rajoitus kerran oli välttämätön, katsottiin niiden, jotka pitkäaikaisen sotapalveluksensa ajalta olivat menettäneet työansionsa ja jotka siten eivät olleet saattaneet kerätä säästövaroja kodin perustamiseen, lähinnä olevan oikeutettuja yhteiskunnan tukeen. Täten koko uudistus oli ainakin toistaiseksi tuleva luonteeltaan väliaikaiseksi.

Toinen merkittävä muutos väestökomitean ehdotukseen nähden oli se, että hallituksen esitykseen ei enää ollut kytketty lapsiavustusjärjestelmää syntyvistä lapsista hyvitettävien kuoletusten muodossa. Sen sijaan lakiehdotukseen sisältyi säännös, että lasten aiheuttama huoltovelvollisuus saattaa olla aiheena harkinnan mukaan tapahtuvaan osittaiseen tai täydelliseen vapauttamiseen lainan takaisinmaksusta niihin vähävaraisiin lainansaajiin nähden, joille on syntynyt kolme tai useampia lapsia. Lapsista koituvat huoltokustannukset tulivat esityksen mukaan otetuiksi huomioon myös siten, että kuoletusten suorittaminen oli keskeytyvä kahdentoista kunkauden ajaksi kullakin kerralla, jolloin syntyy elinkelpoinen lapsi.

Väestökomitean ehdotuksesta hallituksen esitys poikkesi myös siinä suhteessa, että lainat tulisivat olemaan korottomia ja kuoletettavia asetuksella määrättävän ajan kuluessa. Kuoletusten suorittaminen alkaisi vuoden kuluttua kotiuttamisesta. Myös oli esityksestä jätetty pois lainanhakijain terveydentilaa koskeva väestökomitean ehdottama edellytys, koska tämän kysymyksen ratkaise- 
misen katsottiin vaativan laajoja lääketieteellisiä ja oikeudellisia tntkimuksia. Ikärajaksi hallituksen esityksessä ehdotettiin miehille 35 ja naisille 30 vuotta.

Valtioneuvosto oli lakiehdotuksen mukaan vahvistava lainan enimmäismäärän. Lainasumma oli suoritettava lainansaajille ostoosoituksina tai erikoistapauksissa rahana tahi osittain kummassakin muodossa, sen mukaan kuin sosiaaliministeriö tarkemmin määräisi. Kun kaikille lain edellytykset täyttäville aviopareille ei rahataloudellisista syistä voitaisi lainoja myöntää, ehdotettiin lainoja, joiden keskimääräksi oli ajateltu 15.000 markkaa, toistaiseksi annettavaksi menoarvioon otettavan määrärahan puitteissa ministeriön vahvistamien tarkempien perusteiden mukaan vain eniten tarvitseville.

Lainojen hakemis- ja myöntämismenettely oli esityksessä ehdotettu suunnilleen samanlaiseksi kuin komitean mietinnössä. Keskityksen aikaansaamiseksi ehdotettiin sosiaaliministeriöön perustettavaksi kodinperustamislainatoimikunta, jonka kokoonpanosta säädettäisiin asetuksella ja joka käsittelisi lainahakemukset. Paikallisena viranomaisena olisi kaupungin- tai kauppalanhallitus tai kunnallislautakunta.

Lakiehdotuksen eduskuntakäsittelyssä kiinnitettiin arvostelevaa huomiota esityksen erinäisiin yksityiskohtiin. Niinpä työväenasiainvaliokunta piti laina-asiain ratkaisun keskittämistä sosiaaliministeriöön asiain käsittelyä viivästyttävänä ja siihen summittaisuutta aiheuttavana sekä katsoi, ettei luonteeltaan väliaikaisen lain toimeenpanoa varten olisi perustettava uutta viraston osastoa, vaan ehdotti, että lainojen myöntäminen annettaisiin paikallisten huoltoviranomaisten tehtäväksi. Tarkoitukseen käytettävissä olevien rajoitettujen varojen vuoksi olisi tällöin, ellei yleisillä ohjeilla asiasta selvittäisi, etukäteen annettava kunnille tiedot, miten monta - lainaa jokainen niistä enintään voisi myöntää. Lainansaajain ikärajaan nähden valiokunta asettui edistääkseen nuorena naimisiin menoa ja ottaen huomioon valtion rahataloudellisen tilan sille kannalle, että sen myöskin miehen kohdalta olisi oltava vain 30 vuotta. Suuri valiokunta yhtyi muuten työväenasiainvaliokunnan kantaan, mutta laina-asiain käsittelyn suhteen puolsi hallituksen ehdottamaa keskitystä. 'Eduskunta oli samaa mieltä kuin sunri valiokunta hyväksyen siis sekä miehen että naisen ikärajaksi 30 
vuotta ja myöskin 80 äänellä 53 vastaan keskitysperiaatteen. Lakiehdotus hyväksyttiin tämän jälkeen eduskúnnassa yksimielisêsti:

Laki asevelvollisille sotatilanaikaisen palveluksèn pẻrusteella myönnettävistä kodinperustamislainoista vahvistettiin marraskuun 24 päivänä 1944, ja se tuli voimaan seuraavan v́uoden alussa. Marraskuun 30 päivänä samana vuonna annettiin lain toimeenpanoasetus. Siinä m.m. määrättiin, että sosiaaliministeriöön perustettavaan kodinperustamislainatoimikuntaan ministeriö asettaa puheenjohtajan ja varapuheenjohtajana toimivan jäsenen sekä kolme muuta jäsentä ja niille varajäsenet, viimeksimainitut sen jälkeen kun puolụstusministeriö, postisäästöpankin hallitus ja Väestöliitto r.y. kukin ovat esittäneet yhden jäsenen ja yhden varajäsenen. Edelleen määrättiin, että laina on maksettava takaisin joka toisena kuukautena suoritettavilla kuoletusmaksuilla viiden vuoden kuluessa kuoletusten alkamisesta lukien. Samalla säädettiin, että lainaa on haettava viimeistään vuoden 1946 loppuun mennessä. Marraskuun 30 päivänä 1944 antamallaan päätöksellä valtioneuvosto vihdoin määräsi kodinperustamislainan enimmäismääräksi 20.000 markkaa.

Pian kodinperustamislainalain voimaantulon jälkeen havaittiin làin kuitenkin, kuten m.m. edustaja Penna Terv́o y.m. èduskunnalle huhtikuussa 1945 jättämässään lakialoitteessa esittivät, kahdessa suhteessa kaipaavan tarkistusta. Laissa nimittäin oli ensinnäkin säädetty lainan myöntämisen edellytykseksi, että mies lukuunottamatta säännönmukaista palvelusta vakinaisessa väessä on marraskuun 30 päivän 1939 jälkeen palvellut puolustusvoimissa vähintään vuoden ajan tai että hänet edellämainitun päivän jälkeen palveluksen aiheuttaman vamman tai sairauden vuoksi on vapautettu sotapalveluksesta. Koska kuitenkin asevelvollisten nuorimpien ikäluokkien säännönmukainen palvelusaika tammikuun 24 päivänä 1941 vahvistetulla asevelvollisuuslain muutoksellá oli pidennetty kahdeksi vuodeksi, olivat näihin ikäluokkiin kuuluvat joutu* neet lainaa haettaessa huonompaan asemaan kuin muut. Toisená epäkohtana pidettiin sitä, että lakiin miehenkin ikärajaksi oli tullut vain 30 vuotta, eikä 35 , niinkuin hallitus oli ehdottanut. Oli nimit t $^{-}$ täin huomattava, että moni lainan tarpeessa oleva pári oli miehén kotiutumista odotellessaan siirtänyt naimisïnmenonsa myởhem- 
pảă ajankohtaan ja sen johdosta jäänyt kotia perustaessaan ilman yhtéiskunnan tukea, mikä seikka oli aiheuttanut aiheellista tyytymăttömyyttä.

Näiden epäkohtien korjaamista hallitus sitten ehdottikin toukokuun 5 päivänä 1945 èduskunnalle jättämässään esityksessä. Lakiehdotuksen mukaan kodinperustamislainalaissa oli säännönmukaiseksi palvelukseksi vakinaisessa väessä kaikkiin lainanhakijoỉhin nähden luettava vain 350 päivää ja korotettava miehen ikärảja 35 vuodeksi. Asiaa eduskunnassa käsiteltäessä tyôväenasiainvaliokunta yhtyi hallituksen esityksen palvelusaikaa koskevaan kohtaan, mutta ikärajan valiokunta katsoi myös naisen kohdalta olevan korotettavan 35 vuodeksi samoilla perusteilla kuin miehenkin. Myöskin suuri valiokunta ja eduskunta asettuivat samalle kannalle, ja hallituksen esitys siis hyväksyttiin sillä muutoksella, ettầ naisenkin ikäraja määrättiin 35 vuodeksí. Laki asiasta annettiiin kesäkuun 22 päivänä 1945 .

\section{Yleinen kodinperustamislainajärjestelmä toteutetaan} $\therefore+\cdots$

Kodinperustamislainat oli siis valtion rahataloudellisen tilan vuoksi toistaiseksi täytynyt rajoittaa ainoastaan sotapalveluksessa olleita koskevaksi. Rauhanaikaisten olosuhteiden yhä enemmän palautuessa tuli kuitenkin kysymys yleisessä muodossaankin påiväjärjestykseen, sillä naimisiinmenoa estävät tai lykkäävät syyt vaikuttivat yhä niihinkin nuoriin nähden, jotka eivät välittömästi olleet joutuneet sodan johdosta taloudellisesti kärsimään, ei ainoastaan yhtäläisesti, vaan paljon tehokkaamminkin kuin ennen sotia, koska sodanjälkeisissä oloissa on vallinnut kodin perustamisesia tarvittavien esineiden suuri niukkuus ja moninkertaiseksi kohonnut hintataso. Toiselta puolelta taas asevelvollisia koskevan kodinperustamislainan toteuttamisesta oli saatu myönteisiä kokemuksia.

... Lokakuun 18 päivänä 1945 hallitus jätti eduskunnalle esityksên yleiseksi, pysyväksi kodinperustamislainalaiksi, jonka avulla voriaisiin jatkuvasti helpottaa nuorten kodinperustamispyrkimyksiä" ja siten johtaa avioliittoisuuden kehitys yhteiskunnallemme sibobtuisaan suuntaan. Assiasta olivat jo huhtikuussa 1945 edustaja 
Penna Tervo y.m. jättäneet eduskunnalle toivomusaloitteen. Sen perusteluissa puollettiin sotien aiheuttaman väestönmenetyksen korvaamiseksi m.m. sitä järjestelmää, että laina vähitellen lasten syntymisen vaikutuksesta kuoleutuisi.

Paitsi lain laajentamista koskemaan muitakin kuin sotapalveluksessa olleita, hallituksen esitys rakentui suureksi osaksi samalle pohjalle kuin voimassaolevakin laki. Ikärajaksi oli kuitenkin ehdotettu miehiin nähden 30 ja naisten suhteen 28 vuotta, koska alhainen ikäraja naisten kohdalta katsottiin syntyvyydelle melkoista edullisemmaksi. Takaisin laina oli esityksen mukaan maksettava viiden vuoden kuluessa. Uutta oli ja lähentymistä väestökomitean aikoinaan omaksumaan mielipiteeseen ehdotuksessa merkitsi säännös, että milloin lainansaajille lainan myöntämisen jälkeen on syntynyt kolme kuusi kuukautta elänyttä lasta (tähän ei sisältynyt rajoitusta „elinkelpoinen", kuten aikaisemmassa laissa), luetaan kuoletusmaksuna heidän hyväkseen viides osa lainan alkuperäisestä määrästä, kuitenkin vain sikäli, kuin erääntymätöntä lainaa on vielä takaisin maksamatta. Milloin heille on syntynyt neljä mainitun ajan elänyttä lasta, luetaan kuoletusmaksuksi puolet lainan alkuperäisestä määrästä ja milloin on syntynyt viisi lasta, katsotaan lainan tulleen kokonaisuudessaan takaisin maksetuksi. Lainaustoimintaan liittyvät paikalliset tehtävät ehdotettiin hallituksen esityksessä nyt annettaviksi huoltolautakunnille. Lainat oli ehdotuksen mukaan valtion tulo- ja menoarviossa tarkoitukseen varatun määrärahan puitteissa myöntävä sosiaaliministeriö hankittuaan tarpeen mukaan sitä ennen ministeriön kodinperustamislainatoimikunnan lausunnon. Hallituksen esityksessä arvioitiin, olettaen lainojen määräksi keskimäärin 20.000 markkaa, lain toimeenpanosta aiheutuvien kustannusten nousevan noin 65 miljoonaan markkaan.

Lakiehdotuksen käsittelyssä eduskunnassa työväenasiainvaliokunta nytkin aikaisemman kantansa mukaisesti oli sitä mieltä, että miehen ja naisen ikärajan oli oltava sama eli 30 vuotta. Lisäksi valiokunta ehdotti poistettavaksi hallituksen esitykseen sisältyvän rajoituksen, että lasten syntymisen perusteella lainaa kuoletettaessa otettaisiin huomioon vain lainan myöntämisen jälkeen syntyneet lapset. Suuri valiokunta yhtyi työväenasiainvaliokunnan 
kantaan, ja myöskin eduskunta hyväksyi lakiehdotuksen tässä muodossa.

Kodinperustamislainalaki, joka oli tuleva voimaan vuoden 1946 alkaessa, vahvistettiin marraskuun 29 päivänä 1945. Samana päivänä annettiin myös lain toimeenpanoasetus. Tämän sisältämistä säännöksistä mainittakoon, että kuoletuksia oli suoritettava joka toinen kuukausi. Kodinperustamislainatoimikunnasta säädettiin, että siihen määrää sosiaaliministeriö puheenjohtajan ja varapuheenjohtajana toimivan jäsenen sekä neljä muuta jäsentä ja niille varajäsenet, joista yhden jäsenen ja varajäsenen tulee edustaa postisäästöpankin hallitusta, yhden väestön kasvun edistämiseksi ja sen elinehtojen parantamiseksi toimivia järjestöjä ja kahden lainan tarvitsijain piiriä. Lainojen enimmäismääräksi valtioneuvosto samana päivänä antamallaan päätöksellä määräsi 30.000 markkaa.

Koska vuoden 1946 loppuun saakka saatetaan kodinperustamislainoja hakea myöskin asevelvollisia koskevan lain nojalla, oli tarpeen saattaa tämä laki ja uusi yleinen kodinperustamislainalaki tarpeellisessa määrässä yhdenmukaisiksi. Tästä asiasta annettiin eduskunnalle marraskuun 29 päivänä 1945 hallituksen esitys, jonka tarkoituksena oli sopeuttaa aikaisempi laki myöhempään lainahakemusten käsittelyn ja kuolettamismaksujen suorituksen suhteen. Eduskunta hyväksyi lakiehdotuksen tehden myöskin siinä suhteessa asevelvollisia koskevan lain yleisèn kodinperustamislainalain kanssa yhtäpitäväksi, että helpotuksen saamiseksi kuoletusmaksujen suorittamisesta ei ollut tarpeen, että syntynyt lapsi olisi selinkelpoinen", koska valiokunnan mielestä oli syytä ottaa huomioon kustannukset, jotka kaikissa olosuhteissa liittyvät lapsen syntymiseen. Laki asiasta annettiin joulukuun 28 päivänä 1945 .

\section{Väestöliiton osuus lain toimeenpanossa}

Koska kodinperustamislainat annetaan lainansaajille etupäässä määrättyjen tarvikkeiden hankkimiseen oikeuttavina osto-osoituksina, on tärkeätä huolehtia siitä, että heidän saatavissaan sodanjälkeisissä puutteellisissa oloissa on todellakin tarkoituksenmukaista ja kunnollista tavaraa. Lisäksi heille on tarpeen antaa niiden peri- 
aatteiden yleistä ohjausta, joita noudattaen kodinperustamishankinnat olisi suoritettava, koska lainanhakijain itsensä on ratkaistava, minkä tarvikkeiden hankkimiseksi he anovat varoja, ja koska lainahakemusten lopulliseen ratkaisuun vaikuttaa, miten tarkoituksenmukaisesti kodipperustamissuunnitelma on laadittu.

Näiden tehtävien suorittamisen sai osalleen Väestöliitto, joka siten tuli oleellisesti vaikuttamaan kodinperustamislainalain, toimeenpanoon. Liitto on julkaissut kodinperustajia varten kuvitetun ohjekirjasen "Nuorenparin koti», toimeenpannut huonekalutehtaiden, kesken kilpailun nuorillepareille suositeltavien huonekalujen aikaansaamiseksi, järjestänyt kodinperustamisnäyttelyn sekä välittänyt suuria määriä erilaista uusissa kodeissa tarvittavaa tavaraa kodinperustajille. Tätä toimintaa on tarkemmin selostettu Väestöliitọ viiisivuotishistoriikin yhteydessä (ss. 99-101).

\section{Tilastoa kodinperustamislainoista vuonna 1945}

Viime vuonna, minkä kodinperustamislainajärjestelmä vasta on ehtinyt meillä olla käytännössä, sosiaaliministeriön kodinperustamislainatoimikunnassa on Sosiaalisessa Aikakauskirjassa (n:o $9-10$ v. 1945 ja n:o $1-2$ v. 1946) julkaistun tilaston mukaan ollut käsiteltävänä kaikkiaan 5.722 lainahakemusta. Näistä on 5.155 tapauksessa $(90,1 \%)$ ratkaisu ollut myönteinen, ja vain 397 hakemusta $(6,9 \%)$ on hylätty lopullisesti muiden (170 eli $3,0 \%$ ) vielä jäädessä odottamaan lopullista käsittelyä.

Kodinperustamislainoihin oli vuodeksi 1945 valtion tulo-ja menoarviossa varattu 90 miljoonan markan määräraha. Myönnettyjen lainojen yhteissumma nousikin lähes tähän määrään (82.314.500 markkaa). Lainojen keskimääräinen suuruus tuli siten olemaan 15.968 markkaa. Määrättyjen tarvikkeiden hankkimiseen oikeuttavina osto-osoituksina annettiin lainojen yhteissummasta 71.627 .000 markkaa $(87,0 \%)$ ja rahana loput eli 10.687 .500 markkaa $(13,0 \%)$. 5.000 markkaa pienempiä lainoja myönnettiin vain $1(0,02 \%), 5.000$ alle 10.000 markan määräisiä $277(5,4 \%)$, 10.000 alle 15.000 markan $1.288(25,0 \%)$ ja 15.000 markan tai sitä suurempia lainoja kokonaista $3.589 \mathrm{kpl}(69,6 \%)$.

Taloudellisen tuen tarve koteja perustettaessa on kaupungeissa 
ja yleensä asutuskeskuksissa ollut suurin, sillä 3.251 lainaa $(63,1 \%)$ myönnettiin kaupungeissa ja kauppaloissa, mutta vain 1.904 lainaa $(36,9 \%)$ maalaiskunnissa asuville. Kustannukset jakaantuivăt vastaavasti siten, että kaupunkien ja kauppalain osalle tuli 53.305.300 markkaa eli $64,8 \%$ maaseudun osuudeksi jäädessä ainoastaan 29.009.200 markkaa $(35,2 \%)$. Enemmän kuin 10 lainaa myönnettiin 36 kaupungille ja kauppalalle sekä 40 maalaiskunnalle. Helsingin kaupungissa asuville myönnettyjä lainoja oli kokonaista 1.416, tamperelaisille annettuja 309 ja turkulaisille myönnettyjä 234. 3 kaupungista, 2 kauppalasta ja 135 maalaiskunnasta ei saapunut lainahakemuksia lainkaan.

Kuluneena armeijan kotiuttamista seuranneena vuonna oli avioliiton jo solmineita lainansaajista valtaosa eli 4.447 avioparia $(86,3 \%)$ kihloissa olevien parien lukumääräksi jäädessä 708 (13,7 \%). Lapsettomia oli $2.904(56,3 \%)$ ja yksilapsisia $1.649(32,0 \%)$ paria, kun taas kaksi lasta oli 491:1lä $(9,5 \%)$ ja vähintään kolme lasta 111 lainaa hakevalla perheellä $(2,2 \%)$.

Miten myönnetyt lainat sosiaaliministeriön julkaisemien e.m. tietojen pohjalla laaditun tilaston mukaan jakaantuivat maan eri osien kesken, näkyy seuraavista luvuista.

\section{Lääni}

Uudenmaan ...... 1919

Turun ja Porin ...

Ahvenanmaa .....

Hämeen

Kymen

Mikkelin .........

Kuopion .........

Vaasan .........

Oulun

Lapin
Lainoja

\section{Luku}

1919
592

5

767

298

172

477

484

344

97

5155
$\%$

37,2

11,5

0,1

14,9

5,8

3,3

9,2

9,4

6,7

1,9

100,0
Lainojen yhteismäärä Milj. $\mathrm{mk}$

31

9

12

$5 \cdot$

3

7

8

5

2

82
$\%$

38

11

$(0,1)$

15

6

3

9

10

6

2

100,0

Lainansaajain ammattiryhmitystä ja tulosuhteita valaisevat seuraavat yhdistelmät. 
Miehen ammatti

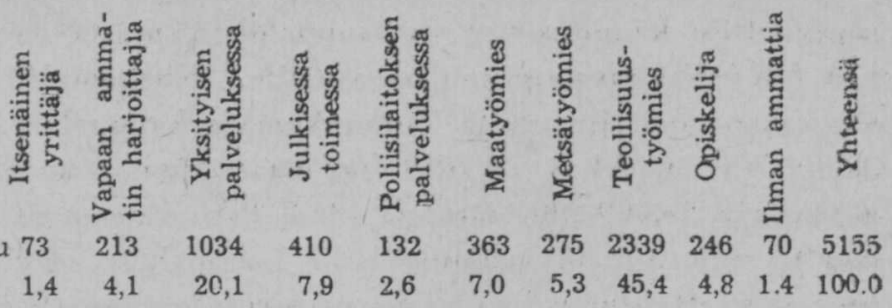

Lainansaajain rahatulot

$\mathrm{ku} \mathrm{ukaudess}$ a, $\mathrm{m} \mathrm{k}$

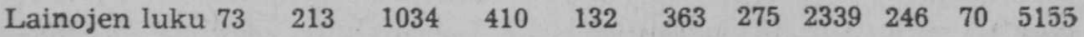

$\begin{array}{llllllllllll}\text { Lainoja, } \% & 1,4 & 4,1 & 20,1 & 7,9 & 2,6 & 7,0 & 5,3 & 45,4 & 4,8 & 1.4 & 100.0\end{array}$

$\begin{array}{lccccccrr} & \text { Alle } & 2500- & 3000 & 4000 & 5000- & 6000 & \text { Yh- } \\ & 2500 & \text { alle } 3000 & \text { alle } 4000 & \text { alle } 5000 & \text { alle } 6000 & & \text { teensä } \\ \text { Lainojen luku } & 593 & 546 & 1170 & 845 & 657 & 1344 & 5155 \\ \text { Lainoja, \% } & 11,5 & 10,6 & 22,7 & 16,4 & 12,7 & 26,1 & 100,0\end{array}$

Lainansaajain asunto-olot kuvastuvat tiedoista, että $51,5 \%$ heistä asui yhden huoneen tai keittiön, 31,7\% yhden huoneen ja keittiön, 3,4\% kahden huoneen ja keittiön sekä $0,2 \%$ kolmen huoneen ja keittiön asunnossa. Kokonaan asunnottomia oli 13,2\%. Vain $2 \%$ lainansaajista omisti itse asuntonsa. 